such a conformation unfavourable. The observed conformation is $21^{\circ}$ from the perpendicular geometry. It appears, therefore, that the observed geometry is a consequence of a balance between two opposing constraints: (i) maximization of orbital overlap between the $\pi$ system of the phenyl group and the cyclopropyl orbitals, and (ii) the unfavourable interaction between $\mathrm{H}(52)$ and $\mathrm{H}(81)$.

The steric compression which prevents the phenyl and carbonyl groups from adopting the bisected conformation could possibly account for the thermal instability of this compound provided that it is relieved in the transition state for decomposition. It is, therefore, difficult to reconcile this interpretation with simple homolytic cleavage of the peroxide bond in the rate-limiting step. Two-bond fission, i.e. synchronous cleavage of the $\mathrm{C}(4) \cdots \mathrm{C}(1)$ and $\mathrm{O}(1) \cdots \mathrm{O}(1 A)$ bonds by either a homolytic mechanism as in certain peroxyesters (Bartlett \& Hiatt, 1958) or more probably, in view of the relatively low intensity of CIDNP, a heterolytic mechanism (Taylor, Govindan \& Kaelin, 1979), provides a more convincing explanation.
References

Allen, F. H. (1980). Acta Cryst. B36, 81-96.

Bartlett, P. D. \& Hiatt, R. R. (1958). J. Am. Chem. Soc. 80, 1398-1405.

Caticha-Ellis, S. A. \& Abrahams, S. C. (1968). Acta Cryst. B24, 277-280.

Germain, G., Main, P. \& Woolfson, M. M. (1970). Acta Cryst. B26, 274-285.

Greene, F. D. \& Kazan, J. (1963). J. Org. Chem. 28, 2168-2171.

Harmony, M. D., Bostrom, R. E. \& Hendricksen, D. K. (1975). J. Chem. Phys. 62, 1599-1600.

Jason, M. E. \& Ibers, J. A. (1977). J. Am. Chem. Soc. 99, 6012-6021.

Karch, N. J. \& McBride, J. M. (1972). J. Am. Chem. Soc. 94, 5092-5093.

LAUler, J. W. \& Ibers, J. A. (1975). J. Am. Chem. Soc. 97, 561-567.

Stewart, J. M., Kruger, G. J., Ammon, H. L., Dickinson, C. \& HALl, S. R. (1972). The XRAY system. Tech. Rep. TR-192. Computer Science Center, University of Maryland, College Park, Maryland.

TAYloR, K. G., Govindan, C. K. \& Kaelin, M. S. (1979). J. Am. Chem. Soc. 101, 2091-2099.

Acta Cryst. (1982). B38, 1679-1681

\title{
Structure of 3,6-Dimethyl-1,4-dioxane-2,5-dione [D-,D-(L-,L-)Lactide]
}

\author{
By G. J. van Hummel and S. HaRkema \\ Chemical Physics Laboratory, Twente University of Technology, PO Box 217, 7500 AE Enschede, \\ The Netherlands \\ AND F. E. KOHN AND J. FEIJEN \\ Polymer Division, Department of Chemical Technology, Twente University of Technology, PO Box 217 , \\ 7500 AE Enschede, The Netherlands
}

(Received 14 October 1981; accepted 26 January 1982)

\begin{abstract}
C}_{6} \mathrm{H}_{8} \mathrm{O}_{4}, M_{r}=144 \cdot 1, P 2_{1} / c, a=8.050$ (2), $b=9.086(1), c=9.713(2) \AA, \beta=102.86(3)^{\circ}, Z=$ $4, V=693 \AA^{3}, D_{x}=1.38 \mathrm{~g} \mathrm{~cm}^{-3}, \mu_{\mathrm{MoK}}=1 \cdot 1 \mathrm{~cm}^{-1}$. Data collection was carried out at $293 \mathrm{~K}$. All hydrogen atoms were located. The molecule has approximate $C_{2}$ symmetry. $R=4 \cdot 6, R_{w}=3 \cdot 8 \%$ for 872 reflexions. The compound $\mathrm{D}-\mathrm{L}$-lactide is shown to be the racemate of D-,D- and L-,L-lactide.
\end{abstract}

Introduction. Over the past fifteen years there has been considerable interest in the application of poly(D-,L-lactic acid) in medicine and surgery (Kronenthal, 1975), for example as a grafting material for perforated eardrums (Feenstra, van der Ven, Kohn \& Feijen, 1980). The preferred method of preparation is the ring-opening polymerization of racemic lactide lor

0567-7408/82/051679-03\$01.00 dilactide, commonly known as D-,L-lactide (Kulkarni, Pani, Neuman \& Leonard, 1966)], a six-membered cyclic diester synthesized from the commercially available racemate of $\mathrm{L}(+)$ - and $\mathrm{D}(-)$-lactic acid.

Substantial synthetic evidence exists (Jungfleisch \& Godschot, 1906; Deane \& Hammond, 1960; Holten, Müller \& Rehbinder, 1971) that the D-,L-lactide (m.p. $400 \mathrm{~K}$ ) routinely used is in fact a racemate of $\mathrm{L}-\mathrm{L}-$ and D-,D-lactide (m.p. $368 \mathrm{~K}$ ). This fact has not been appreciated generally. Some authors (Fouty, 1973; Gregory, Schwope \& Wise, 1973; Sinclair, 1977) suggest that D-,L-lactide consists of meso-lactide molecules. In polymers derived from the meso-lactide the stereo sequence cannot contain more than two $D$ - or L-lactate units in succession. A racemate of D-,D- and $\mathrm{L}$-, L-lactide allows, in principle, the formation of stereo

(C) 1982 International Union of Crystallography 
block-type copolymers (Lillie \& Schulz, 1975; Schindler \& Harper, 1976).

Crude D-,L-lactide was prepared according to Sinclair \& Gynn (1972). From this product two compounds could be obtained, one melting at $400 \mathrm{~K}$ and one melting at $316 \mathrm{~K}$. Suitable crystals (maximum dimension $0.4 \mathrm{~mm}$ ) of the compound, melting at $400 \mathrm{~K}$, were obtained by controlled recrystallization from dry ether.

In this paper the first X-ray structure elucidation of racemic lactide is reported.

Intensities up to $\theta=25^{\circ}$ were collected at $293 \mathrm{~K}$ on a Philips PW1100 single-crystal diffractometer, using the $\omega-2 \theta$ scanning technique [scan width: $(2+$ $\left.\tan \theta)^{\circ}\right]$, with graphite-monochromatized MoKa radiation. The scan speed was $0.03^{\circ} \mathrm{s}^{-1}$. The total background measuring time was scan time $\times\left(I_{\text {backgr }} /\right.$ $\left.I_{\text {peak }}\right)^{1 / 2}$, with a minimum of $5 \mathrm{~s}$ at each side of the peak. The number of reflexions measured was 1294 , of which 872 were considered significant $\mid I>\sigma(I)$, where $\sigma(I)$ is the standard deviation from counting statistics].

The structure was solved by direct methods (Germain, Main \& Woolfson, 1971) and refined with a local version of ORFLS (Busing, Martin \& Levy, 1962). The function minimized was $\sum w\left(\left|F_{o}\right|-k\left|F_{c}\right|\right)^{2}$ with $w=$ $\sigma^{-2}(F) . \sigma(F)$ was calculated from $\sigma(I)+0.01\left|F_{o}\right|$. The atomic scattering factors were taken from International Tables for X-ray Crystallography (1974). The parameters refined were the scaling factor, positional parameters for all atoms and anisotropic temperature factors for the non-hydrogen atoms. For $\mathrm{H}$ atoms isotropic temperature factors were refined. Extinction corrections were applied. The final unweighted and weighted $R$ factors were 4.6 and $3.8 \%$ respectively, for the significant reflexions.

Discussion. The asymmetric unit consists of one molecule of lactide. Atomic coordinates are given in Table $1^{*}$ (see Fig. 1 for atom numbering); Tables 2 and 3 contain bond distances and angles, and torsion angles. Within experimental error, the molecule has $C_{2}$ symmetry, as is to be expected for D-,D- and L-,L-type molecules. Owing to space-group symmetry both types are present in the cell. The cyclic group has an irregular skew boat conformation, in which (see Table 3) two almost planar groups occur: $\{\mathrm{O}(4), \mathrm{C}(3), \mathrm{C}(8), \mathrm{O}(1)$, $\mathrm{C}(5),[\mathrm{C}(7)]\}$ and $\{\mathrm{O}(9), \mathrm{C}(6), \mathrm{C}(5), \mathrm{O}(2), \mathrm{C}(8)$, $[\mathrm{C}(10)]\}$.

Fig. 2 shows the molecular packing. The shortest intermolecular distance is $\mathrm{O}(9) \cdots \mathrm{H}(2)=2.33(2) \AA$ $[\mathrm{C}(5) \ldots \mathrm{O}(9)=3.202(4) \AA]$. The results of this

\footnotetext{
* Lists of structure factors, anisotropic thermal parameters and bond lengths and angles involving hydrogen have been deposited with the British Library Lending Division as Supplementary Publication No. SUP 36647 (10 pp.). Copies may be obtained through The Executive Secretary, International Union of Crystallography, 5 Abbey Square, Chester CH1 2HU, England.
}

crystal structure determination show that D-,L-lactide (m.p. $400 \mathrm{~K}$ ) is the racemate of D-, D- and L-, L-lactide and not the meso form of this lactide.

The synthetic results obtained by Jungfleisch \& Godschot (1906) and Deane \& Hammond (1960), as

Table 1. Fractional atomic coordinates $\left(\times 10^{4}\right.$; $\left.\mathrm{H} \times 10^{3}\right)$ and equivalent isotropic thermal parameters

$$
\left(\AA^{2} \times 10^{3}\right)
$$

$\begin{array}{lcccc} & x & y & z & U_{\mathrm{eq}}{ }^{*} \\ \mathrm{O}(1) & 6386(2) & 9651(2) & 6789(2) & 55(1) \\ \mathrm{O}(2) & 6130(2) & 7170(2) & 5179(2) & 58(1) \\ \mathrm{C}(3) & 4863(3) & 8986(3) & 6465(3) & 49(1) \\ \mathrm{O}(4) & 3605(2) & 9665(2) & 6522(2) & 71(1) \\ \mathrm{C}(5) & 7909(3) & 8742(3) & 6907(3) & 56(1) \\ \mathrm{C}(6) & 7692(3) & 7729(3) & 5664(3) & 52(1) \\ \mathrm{C}(7) & 9401(4) & 9748(5) & 7070(5) & 84(2) \\ \mathrm{C}(8) & 4878(3) & 7394(3) & 6033(3) & 55(1) \\ \mathrm{O}(9) & 8831(2) & 7400(2) & 5108(2) & 76(1) \\ \mathrm{C}(10) & 3209(4) & 6872(4) & 5169(5) & 79(1) \\ \mathrm{H}(1) & 796(3) & 813(3) & 770(3) & 66(8) \\ \mathrm{H}(2) & 1049(4) & 918(3) & 713(3) & 74(8) \\ \mathrm{H}(3) & 524(3) & 684(3) & 691(3) & 61(8) \\ \mathrm{H}(4) & 236(4) & 704(3) & 566(3) & 77(10) \\ \mathrm{H}(5) & 328(4) & 583(4) & 494(4) & 93(11) \\ \mathrm{H}(6) & 292(3) & 738(4) & 425(3) & 75(10) \\ \mathrm{H}(7) & 926(4) & 1035(4) & 623(4) & 87(13) \\ \mathrm{H}(8) & 950(5) & 1032(4) & 793(5) & 114(14)\end{array}$

* Defined according to Willis \& Pryor (1975).

Table 2. Bond distances $(\AA)$ and angles $\left(^{\circ}\right)$

$\begin{array}{llll}\mathrm{O}(1)-\mathrm{C}(3) & 1.340(3) & \mathrm{C}(3)-\mathrm{C}(8) & 1.507(3) \\ \mathrm{O}(1)-\mathrm{C}(5) & 1.462(3) & \mathrm{C}(5)-\mathrm{C}(6) & 1.497(4) \\ \mathrm{O}(2)-\mathrm{C}(6) & 1.341(3) & \mathrm{C}(5)-\mathrm{C}(7) & 1.490(5) \\ \mathrm{O}(2)-\mathrm{C}(8) & 1.455(3) & \mathrm{C}(6)-\mathrm{O}(9) & 1.200(3) \\ \mathrm{C}(3)-\mathrm{O}(4) & 1.197(3) & \mathrm{C}(8)-\mathrm{C}(10) & 1.494(5) \\ \mathrm{C}(3)-\mathrm{O}(1)-\mathrm{C}(5) & 118.1(3) & \mathrm{C}(6)-\mathrm{C}(5)-\mathrm{C}(7) & 114.2(3) \\ \mathrm{C}(6)-\mathrm{O}(2)-\mathrm{C}(8) & 117.5(3) & \mathrm{O}(2)-\mathrm{C}(6)-\mathrm{C}(5) & 116.6(3) \\ \mathrm{O}(1)-\mathrm{C}(3)-\mathrm{O}(4) & 119.7(3) & \mathrm{O}(2)-\mathrm{C}(6)-\mathrm{O}(9) & 119.9(3) \\ \mathrm{O}(1)-\mathrm{C}(3)-\mathrm{C}(8) & 115.7(2) & \mathrm{C}(5)-\mathrm{C}(6)-\mathrm{O}(9) & 123.5(3) \\ \mathrm{O}(4)-\mathrm{C}(3)-\mathrm{C}(8) & 124.5(3) & \mathrm{O}(2)-\mathrm{C}(8)-\mathrm{C}(3) & 110.0(2) \\ \mathrm{O}(1)-\mathrm{C}(5)-\mathrm{C}(6) & 109.8(2) & \mathrm{O}(2)-\mathrm{C}(8)-\mathrm{C}(10) & 106.6(3) \\ \mathrm{O}(1)-\mathrm{C}(5)-\mathrm{C}(7) & 107.7(3) & \mathrm{C}(3)-\mathrm{C}(8)-\mathrm{C}(10) & 113.5(3)\end{array}$

Table 3. Pairwise comparison of torsion angles $\left(^{\circ}\right)$

\begin{tabular}{lccc}
$\mathrm{C}(5)-\mathrm{O}(1)-\mathrm{C}(3)-\mathrm{O}(4)$ & $171 \cdot 3(2)$ & $\mathrm{C}(8)-\mathrm{O}(2)-\mathrm{C}(6)-\mathrm{O}(9)$ & $169.5(2)$ \\
${ }^{*} \mathrm{C}(5)-\mathrm{O}(1)-\mathrm{C}(3)-\mathrm{C}(8)$ & $-9.2(3)$ & ${ }^{*} \mathrm{C}(8)-\mathrm{O}(2)-\mathrm{C}(6)-\mathrm{O}(5)$ & $-10 \cdot 1(3)$ \\
${ }^{*} \mathrm{O}(1)-\mathrm{C}(3)-\mathrm{C}(8)-\mathrm{O}(2)$ & $-38 \cdot 2(3)$ & ${ }^{*} \mathrm{O}(2)-\mathrm{C}(6)-\mathrm{C}(5)-\mathrm{O}(1)$ & $-37.1(3)$ \\
$\mathrm{O}(1)-\mathrm{C}(3)-\mathrm{C}(8)-\mathrm{C}(10)$ & $-157.5(3)$ & $\mathrm{O}(2)-\mathrm{C}(6)-\mathrm{C}(5)-\mathrm{C}(7)$ & $-158.2(3)$ \\
$\mathrm{O}(1)-\mathrm{C}(3)-\mathrm{C}(8)-\mathrm{H}(3)$ & $79(2)$ & $\mathrm{O}(2)-\mathrm{C}(6)-\mathrm{C}(5)-\mathrm{H}(1)$ & $77(2)$ \\
$\mathrm{O}(4)-\mathrm{C}(3)-\mathrm{C}(8)-\mathrm{O}(2)$ & $141 \cdot 3(2)$ & $\mathrm{O}(9)-\mathrm{C}(6)-\mathrm{C}(5)-\mathrm{O}(1)$ & $143.4(3)$ \\
$\mathrm{O}(4)-\mathrm{C}(3)-\mathrm{C}(8)-\mathrm{C}(10)$ & $22 \cdot 0(4)$ & $\mathrm{O}(9)-\mathrm{C}(6)-\mathrm{C}(5)-\mathrm{C}(7)$ & $22.3(4)$ \\
$\mathrm{O}(4)-\mathrm{C}(3)-\mathrm{C}(8)-\mathrm{H}(3)$ & $-102(2)$ & $\mathrm{O}(9)-\mathrm{C}(6)-\mathrm{C}(5)-\mathrm{H}(1)$ & $-102(2)$ \\
${ }^{*} \mathrm{C}(3)-\mathrm{C}(8)-\mathrm{O}(2)-\mathrm{C}(6)$ & $48.4(3)$ & ${ }^{*} \mathrm{C}(6)-\mathrm{C}(5)-\mathrm{O}(1)-\mathrm{C}(3)$ & $47.2(3)$ \\
$\mathrm{C}(10)-\mathrm{C}(8)-\mathrm{O}(2)-\mathrm{C}(6)$ & $171.8(2)$ & $\mathrm{C}(7)-\mathrm{C}(5)-\mathrm{O}(1)-\mathrm{C}(3)$ & $172.2(3)$ \\
$\mathrm{H}(3)-\mathrm{C}(8)-\mathrm{O}(2)-\mathrm{C}(6)$ & $-67(2)$ & $\mathrm{H}(1)-\mathrm{C}(5)-\mathrm{O}(1)-\mathrm{C}(3)$ & $-67(2)$ \\
$\mathrm{O}(1)-\mathrm{C}(5)-\mathrm{C}(7)-\mathrm{H}(2)$ & $-179(2)$ & $\mathrm{O}(2)-\mathrm{C}(8)-\mathrm{C}(10)-\mathrm{H}(4)$ & $-177(2)$ \\
$\mathrm{O}(1)-\mathrm{C}(5)-\mathrm{C}(7)-\mathrm{H}(7)$ & $-62(2)$ & $\mathrm{O}(2)-\mathrm{C}(8)-\mathrm{C}(10)-\mathrm{H}(6)$ & $-56(2)$ \\
$\mathrm{O}(1)-\mathrm{C}(5)-\mathrm{C}(7)-\mathrm{H}(8)$ & $62(2)$ & $\mathrm{O}(2)-\mathrm{C}(8)-\mathrm{C}(10)-\mathrm{H}(5)$ & $60(2)$ \\
\multicolumn{5}{c}{ * Torsion angles in the cyclic group. }
\end{tabular}




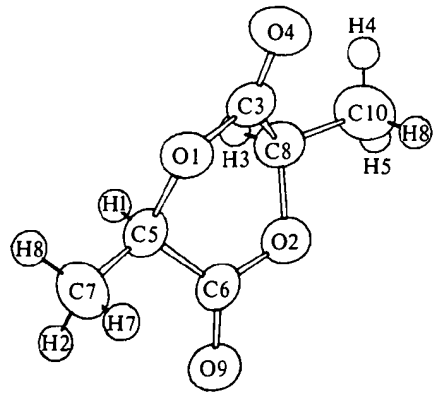

Fig. 1. The D-,D-lactide molecule showing the atomic numbering.
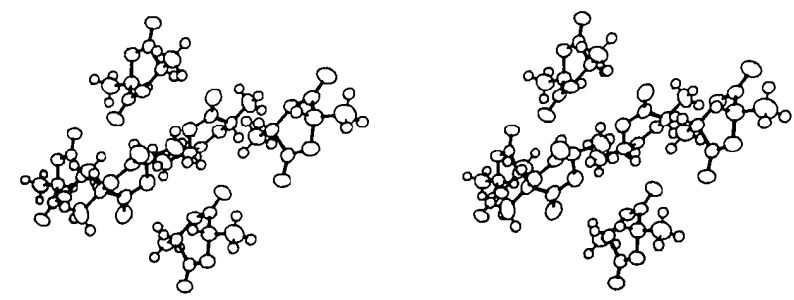

Fig. 2. Stereoscopic view of the molecular packing.

interpreted by Holten et al. (1971) are in agreement with our results. Therefore, in principle, polymers derived from the title compound may contain longer isotactic sequences.

\section{References}

Busing, W. R., Martin, K. O. \& Levy, H. A. (1962). ORFLS, Report ORNL-TM-305. Oak Ridge National Laboratory, Tennessee.
Deane, D. D. \& Hammond, E. G. (1960). J. Dairy Sci. 43, $1421-1429$.

Feenstra, L., van der Ven, B. W. C., Kohn, F. E. \& Feluen, J. (1980). Int. J. Artif. Organs, 3, 354-357.

Fouty, R. A. (1973). Assignor to Ethicon, Inc. Canadian patent No. 923245.

Germain, G., Main, P. \& Woolfson, M. M. (1971). Acta Cryst. A27, 368-376.

Gregory, J. B., Schwope, A. D. \& Wise, D. L. (1973). AD Report No. 759381. US National Technical Information Service.

Holten, C. H., Müller, A. \& Rehbinder, D. (1971). Lactic Acid, pp. 221-224. Weinheim: Verlag Chemie.

International Tables for X-ray Crystallography (1974). Vol. IV. Birmingham: Kynoch Press.

Jungfleisch, E. \& Godschot, M. (1906). C. R. Acad. Sci. 142, 637-639.

Kronenthal, R. L. (1975). Polymers in Medicine and Surgery, edited by R. L. Kronenthal, Z. OsER \& E. Martin, pp. 119-137. New York and London: Plenum.

Kulkarni, R. K., Pani, K. C., Neuman, C. \& Leonard, F. (1966). AD Report No. 636716. US National Technical Information Service.

Lillie, E. \& Schulz, R. C. (1975). Makromol. Chem. 176, 1901-1906.

Schindler, A. \& Harper, D. (1976). Polym. Lett. 14, 729-734.

Sinclair, R. G. (1977). Assignor to Gulf Oil Corp. US patent No. 4045418.

Sinclair, R. G. \& GYNN, G. M. (1972). AD Report No. 748411 . US National Technical Information Service.

Willis, B. T. M. \& PRYOR, A. W. (1975). Thermal Vibrations in Crystallography, pp. 101-102. Cambridge Univ. Press.

\section{SHORT COMMUNICATIONS}

Contributions intended for publication under this heading should be expressly so marked; they should not exceed about 1000 words; they should be forwarded in the usual way to the appropriate Co-editor; they will be published as speedily as possible.

Acta Cryst. (1982). B38, 1681-1682

Standard deviations obtained from block-diagonal least-squares matrices. By JoEL N. FRANKLIN, Department of Applied Mathematics, California Institute of Technology, Pasadena, California 91125 and RICHARD E. MARSH, Department of Chemistry, ${ }^{*}$ California Institute of Technology, Pasadena, California 91125, USA.

(Received 6 April 1981; accepted 5 January 1982)

\begin{abstract}
It is demonstrated that the estimated standard deviations of parameters obtained from partial-matrix least-squares refine-

* Contribution No. 6419 from the Arthur Amos Noyes Laboratory of Chemical Physics.
\end{abstract}

$0567-7408 / 82 / 051681-02 \$ 01.00$ ment are smaller than, or equal to, the corresponding standard deviations obtained from full-matrix refinement.

It is the purpose of this note to demonstrate that a standard deviation obtained from a diagonal, or from any form of block-diagonal, least-squares refinement is a minimum (C) 1982 International Union of Crystallography 